\title{
A Systematic Review of Technological Impact on Math Literacy in the Postsecondary Classrooms
}

\author{
Manuel Rodriguez ${ }^{1}$ \\ ${ }^{1}$ General Education, Westcoast University, Doral, USA \\ Correspondence: Manuel Rodriguez, 4675 SW 128th Avenue, Miami, FL 33175, USA. Tel: 1-786-525-7307. \\ E-mail: Manrodriguez@westcoastuniversity.edu
}

Received: September 4, 2020

Accepted: October 21, $2020 \quad$ Online Published: October 29, 2020

doi:10.5539/hes.v10n4p54

URL: https://doi.org/10.5539/hes.v10n4p54

\begin{abstract}
The purpose of this systematic review was to evaluate contemporary literature related to the impact of technology on student success for postsecondary mathematics courses. The aim of this review was to provide a comprehensive understanding of the extant literature concerning's student success in mathematics for higher-education students. A series of seven databases were accessed across the past five years, which resulted in fourteen key studies. The findings of this study demonstrate the current knowledge and recommendations for future researchers. Technology was elucidated as a meaningful approach for increasing student success, course grades, and retention. However, a critical need for future empirical assessments was elucidated.
\end{abstract}

Keywords: technological and education, mathematics education, postsecondary education, technology impact on student success, higher education and technology

\section{Introduction}

Technological inclusion within the classroom originated in the early 1970s (Davison \& Lazaros, 2015). The increased reliance towards technology as a tool outside of education led to researcher focus on the impact within the classroom. Initial assessments were primarily guided towards K-12 classrooms, which failed to provide an understanding of the impact of technology within higher education (Davison \& Lazaros, 2015). As a result, technological based instructional design was incorporated mainly as a tool for instruction. However, since the early 1970s, technological tools and paradigms for inclusion within instruction has greatly improved (Esteves et al., 2017; Davison \& Lazaros, 2015).

The inclusion of technology within mathematics was originally fostered as a unique approach to addressing poor student outcomes. However, researchers and educators noted that only a few tools are used for technological integration within mathematics courses. Overall, the understanding of the use of technology for student outcomes in mathematics classes is lacking in the extant literature. As such, the purpose of this systematic review was to establish the contemporary literature in the past five years (e.g., 2016-2020) to establishes the known impact of technology upon math literary in postsecondary courses. For this purpose, two key research questions were posed:

(1) What is the current assessment of technology use for postsecondary math?

(2) What are the most commonly used forms of technology for postsecondary math classrooms?

(3) What are the current known student learning outcomes for technology use in postsecondary math classrooms?

In this article, a systematic review is provided to address these research questions. However, first, a discussion of the background to the inclusion of technology in mathematics is provided.

\section{Background}

\subsection{Technology in the Classroom}

Technological inclusion in the classroom is noted to impact a variety of student outcomes, such as engagement, literary, and critical thinking and problem-solving skills (Marinagi, Skourlas, \& Belsis, 2013). The inclusion of technology can be framed as how Davison and Lazaros (2015) considered the shift to technology in the classroom as "knowledge procurement to a more interactive form of learning (p. 31)." For $21^{\text {st }}$ century students, 
technology ranges from mobile tablets to classroom specific technological aids (Marinagi et al., 2013). The technological environment for some classes may include gaining knowledge from the internet and using web applications, computers, phones, and tablets to communicate with peers and educators (Marinagi et al., 2013).

However, the form of technology and the level of usage and reliance is highly dependent upon the classroom, the educator, and even the university setting (Esteves et al., 2017). One example of technology use variation was provided by Esteves et al. (2017) review of higher education applications, which included games for retention that were played on student iPhone. Esteves et al. (2017) noted that students found mobile games to be engaging and also added to the retention of the classroom subject matter. Variations of student technology use in higher education includes blogging (Garcia, Moizer, Wilkins, \& Haddoud, 2019), Google Classroom for online learning (Kumar \& Bervell, 2019), and online project 3D modeling for science classes (Torio, 2019).

\subsubsection{Mathematics and Technology}

Students in higher education notably struggle with the demands of math courses (Aldon, Hitt, Bazzini, \& Gellert, 2017; Driskell et al., 2018). Resultantly, literature reflects a continued focus on educator professional development (Driskell et al., 2018), improving class objectives and course clarity (Garrett et al., 2019), and more recently focusing on technology inclusion for improving student learning (Ball \& Barzel, 2018; Garrett et al., 2019).

However, literature demonstrating the outcomes of student learning for higher education math students is less abundant in reviewed literature (Holzberger et al., 2020). Yet, preliminary findings suggest that technology is central to increasing student engagement, course grades, and overall math literary (Cohen \& Kelly, 2019). However, the general format of technology usage, the outcome on student grades and literary, and the most commonly used form of technology is generally absent from academic assessments.

As a result, there is a noted need to understand the outcomes of technology based on the reported findings of previous researchers. Ideally, understanding the contemporary status of technology use for student outcomes in higher education math classes will further delineate new framework for future researchers.

\section{Methods and Materials}

For this study, the data collection and analysis methods were based on the guidelines of Petticrew and Roberts (2006) systematic review framework. For this assessment, the following research questions were first delineated:

(1) What is the current assessment of technology use for postsecondary math?

(2) What are the most commonly used forms of technology for postsecondary math classrooms?

(3) What are the current known student learning outcomes for technology use in postsecondary math classrooms?

\subsection{Data Collection}

For the purpose of this study, a systematic review using the framework of Petticrew and Roberts (2006) and the PRISMA (Preferred Reporting Items for Systematic Reviews and Meta-Analyses) flow guideline was adapted. The research questions provided were framed by a preliminary investigation of the known literature. The gaps noted in the reviewed literature framed the guiding research questions and aided in the established search strategy.

\subsubsection{Search Strategy}

For this study, the key databases assessed included, ERIC, EBSCO Host and Database, SCOPUS, Science Direct, Directory of Open Access Journals, JSTOR, and Web of Science. The following keywords were defined for searching within each of the databases: education and technology, "OR" higher education and technology, "AND" higher education math and technology, "AND" student outcomes "AND" higher education math, "AND" student outcomes "AND" mathematics "AND" technology.

In addition to a set of databases and keywords, a series of inclusion criteria were established:

(1) Publication from the past five-years (e.g., 2016-2020)

(2) English language

(3) Full text available

(4) Must assess higher education, mathematics, and technology

The reasoning for these specific guidelines was to ensure that the contemporary data was accessed. Additionally, a preference to English language was provided to mitigate possible translation bias or error for non-English texts. 
Finally, full text only was included as a means of ensuring that the researcher could explore the findings, results, and implications as reported by each author.

\section{Results}

The results of this study demonstrated 169 studies. However, 12 studies were eliminated from the findings due to failure to meet the established criteria delineated for this study. The PRISMA flow guideline is demonstrated in Table 1. The results of the PRISMA systematic review is presented as organized by each research question, which are presented by the first research question in the following section.

Table 1. PRISMA Analysis Results

\begin{tabular}{|c|c|c|c|}
\hline Identification & Keywords & $\begin{array}{l}\text { Education and technology, "( } \\
\text { "AND" higher education } m \\
\text { outcomes "AND" higher edu } \\
\text { "AND" mathematics "AND" } t\end{array}$ & $\begin{array}{l}\text { R" higher education and technology, } \\
\text { ath and technology, "AND" student } \\
\text { ation math, "AND" student outcomes } \\
\text { chnology. }\end{array}$ \\
\hline & Database & & Studies \\
\hline & $\begin{array}{l}\text { EBSCO Host } \\
\text { and Database }\end{array}$ & & 95 \\
\hline & Web of Science. & & 45 \\
\hline & ERIC & & 130 \\
\hline & SCOPUS & & 120 \\
\hline & Science Direct & & 120 \\
\hline & JSTOR & & 135 \\
\hline & Directory of & & 185 \\
\hline Screening & Open Access Journals & & \\
\hline Screening & Studies identified thr & ugh databases $(n=830)$ & \\
\hline & $\begin{array}{l}\text { Duplicate studies ren } \\
\text { Studies screened }(\mathrm{n}=\end{array}$ & ved $(n=120)$ & \\
\hline & Studies excluded that & lid not meet criteria $(n=169)$ & \\
\hline Synthesis & Studies included for & nthesis $(\mathrm{n}=12)$ & \\
\hline
\end{tabular}

\subsection{Technology Use in Postsecondary Math}

The first research question posed in this study addressed: (1) what is the current assessment of technology use for postsecondary math? Resultantly, 12 studies were identified that met the inclusion criteria for this study (Table 2). A dearth of the reviewed literature focused on systematic reviews that were specific towards the course or field, such as STEM based degrees (Abramovich et al., 2016; Ralph, 2016). Secondly, researchers Buteau and Muller (2017) demonstrated that technology is key for mathematics courses, specially programming based courses. However, the student outcomes regarding course grades and literacy was not reported by Buteau and Muller (2017). 
Table 2. Technology Use in Postsecondary Math

\begin{tabular}{|c|c|}
\hline Author & Key Results and Context \\
\hline Ralph, 2016 & $\begin{array}{l}\text { Systematic review of STEM outcomes using technology. Positive results } \\
\text { for technology use. }\end{array}$ \\
\hline Buteau \& Muller, 2017 & $\begin{array}{l}\text { Review of assigned undergraduate projects in mathematics programming } \\
\text { courses. Benefits elucidated for coding programs. }\end{array}$ \\
\hline Dani \& Nasser, 2016 & Established positive effects for online tutoring in math courses. \\
\hline Bond, 2016 & $\begin{array}{l}\text { Explored impact of online learning communities for math courses in } \\
\text { university contexts. }\end{array}$ \\
\hline $\begin{array}{l}\text { Abramovich, Burns, } \\
\& \text { Campbell (2016). }\end{array}$ & $\begin{array}{l}\text { Explored STEM outcomes for technology usage, such as graphic } \\
\text { calculators and desktop programs specific to the course. }\end{array}$ \\
\hline $\begin{array}{l}\text { De Araujo, Otten, } \\
\& \text { Birisci, } 2017\end{array}$ & $\begin{array}{l}\text { Illustrated positive student outcomes for online homework and in-class } \\
\text { activities. }\end{array}$ \\
\hline Buch \& Warren, 2017 & $\begin{array}{l}\text { Demonstrated positive student outcomes for flipped classroom with } \\
\text { technology }\end{array}$ \\
\hline Chen \& Wu, 2020 & $\begin{array}{l}\text { Illustrated positive student perception of technology integration for } \\
\text { remedial math students. }\end{array}$ \\
\hline $\begin{array}{l}\text { Tobin, Weiss, \& } \\
\text { Vida, } 2016\end{array}$ & Illustrated that CAS technology was effective for mathematics students. \\
\hline $\begin{array}{l}\text { Levi, Chahine, Garett, \& } \\
\text { Wang, } 2016\end{array}$ & $\begin{array}{l}\text { Demonstrated positive student outcomes through technology in math } \\
\text { courses }\end{array}$ \\
\hline Elli et al., 2020 & $\begin{array}{l}\text { Explored narrowing achievement gap through technology in science and } \\
\text { math courses. }\end{array}$ \\
\hline
\end{tabular}

Focus was also placed towards online services for math courses, such as tutoring of math courses in online portals or through community peer groups for each class (Bond, 2016, Dani \& Nasser, 2016). Multiple authors also demonstrated that the flipped classroom model was effective for student outcomes and learning in math courses (Buch \& Warren, 2017; De Araujo, Otton, \& Birisci, 2017). Chen and Wu (2020) also demonstrated that technology is essential to improving math grades for students in remedial courses.

Literature also reflected that achievement gaps can be reduced through the incorporation of technology within science and math classes (Eli et al., 2020). Further, Levi, Chahine, Garrett, and Wang (2016) demonstrated that the use of technology in math courses encourages active learning, retention, and engagement. However, barriers to technology usage, such as professor disregard, was also noted (Tobin, Weiss, \& Vida, 2016).

\subsubsection{Common Forms of Technology in Math Classrooms}

The second question posed in this study, was (2) what are the most commonly used forms of technology for postsecondary math classrooms? Resultantly, four key studies revealed information specific to this question. However, reporting's regarding the specific technology was notably absent in the remaining eight studies identified in the systematic review (Table 3).

Table 3. Commonly Used forms of Technology

\begin{tabular}{ll}
\hline Author & Key Results and Context \\
\hline Buch \& Warren, 2017 & Pre-recorded videos \\
De Araujo, Otten, \& Birisci, 2017 & $\begin{array}{l}\text { Demonstrated the use of online homework and in-class activities } \\
\text { through a computer program specific to the university. }\end{array}$ \\
Tobin, Weiss, \& Vida, 2016 & $\begin{array}{l}\text { Graphic calculator usage } \\
\text { Levi, Chahine, Garett, \& Wang (2016) }\end{array}$ \\
Homework support and tutorials in online formats \\
\hline
\end{tabular}

The most commonly reported technological method was the use of online portals for homework, communication, and peer work (Buch \& Warren, 2017). Buch and Warren (2017) reported the use of pre-recorded videos to successfully aid students struggling in math courses. Similarly, De Araujo, Otten, and Birisci (2017) and Levi, Chahine, Garett, and Wang (216) identified that online homework through a math specific software aided student in retention and engagement. Finally, Tobin, Weiss, and Vida (2016) reported use of graphical calculator for math classes; however, barriers were noted to professor willingness to incorporate calculator technology. 


\subsubsection{Student Outcomes for Technology Use in Math Courses}

The final research question, addressed (3) what are the current known student learning outcomes for technology use in postsecondary math classrooms? Resultantly, five studies were identified that provided information regarding student learning outcomes (Table 4).

Table 4. Student Outcomes for Technology use in Postsecondary Math Courses

\begin{tabular}{ll}
\hline Author & Key Results and Context \\
\hline Buch \& Warren (2017) & $\begin{array}{l}\text { Explored student outcomes for technology usage in a flipped classroom for } \\
\text { mathematics courses. }\end{array}$ \\
$\begin{array}{l}\text { De Araujo, Otten, \& } \\
\text { Birisci, 2017 }\end{array}$ & $\begin{array}{l}\text { Illustrated positive student outcomes for online homework and in-class activities. } \\
\text { Chen \& Wu, 2020 }\end{array}$ \\
$\begin{array}{l}\text { Student perception of course usefulness and perception of technology improved } \\
\text { in remedial math courses. Post-tests were also higher for integrated courses. }\end{array}$ \\
$\begin{array}{l}\text { Wevi, Chahine, Garett, \& (2016) } \\
\text { Elli et al., 2020 }\end{array}$ & $\begin{array}{l}\text { Student post-tests increased as well as engagement and active learning. } \\
\text { and science courses }\end{array}$ \\
\hline
\end{tabular}

The use of technology in math courses proved for the reviewed authors to positively impact student learning outcomes and grades (Buch \& Warren, 2017; Chen \& Wu, 2020; Elli et al., 2020; De Arujo et al., 2017; Levi et al., 2016). Researchers Buch and Warren (2017) provided a key assessment of the outcome of technology on student learning through a review of questionnaires provided to students that were in technology integrated math courses. The authors also explored student performances based on grade outcomes. Resultantly, $60 \%$ of the participating students reported high satisfaction with the course. Further, 92\% agreed that technology inclusion was important within a flipped classroom design. Buch and Warren (2017) also reported that grades for the technology classroom were 10\% higher than the traditional lecture style classroom for math courses. Similarly, $\mathrm{Chu}$ and $\mathrm{Wu}$ (2020) also demonstrated that integrated methods for remedial math increased student post-test scores

Student outcomes were also noted to be connected with retention and engagement. De Araujo et al. (2017) noted that the inclusion of online homework and a specialized math software was effective for student perceptions of learning and retention within math. Levi et al. (2016) also illustrated that factors of active learning, engagement, and retention are increased with technology inclusion.

Active learning was also increased through the inclusion of technology. Research from Eli et al. (2020) also found that active learning, through technology and flipped classrooms can reduce the achievement gap for undergraduate students. The authors explored data from 15 studies, which included 9,238 students. Through the use of Bayesian regression analysis, achievement gap was decreased from 33\% to 45\%. Thus, indicating the positive impact of technology upon student outcomes.

\section{Discussion}

The resultant findings from this systematic review demonstrated two central themes that may aid future researchers as well as initiate continued discourse regarding the inclusion of technology within mathematics courses in postsecondary education:

(1) Efficacy of technology for teaching student's math

(2) Improved student outcomes for inclusion of technology in math courses

Technology was a noted critical mediator for improving the learning and engagement of students in math courses (Abramovich et al., 2016; Ralph, 2016). Researchers further demonstrated that student outcome results were furthered through the inclusion of technology Buch \& Warren, 2017; Chen \& Wu, 2020; Elli et al., 2020; De Arujo et al., 2017; Levi et al., 2016). The findings demonstrated that inclusion of technology within the math classroom can also serve to increase the active-learning processes of students, which can serve benefit students that struggle in mathematics classes.

A key barrier to technology inclusion was also noted in reviewing previous literature. Educators in higher education courses for math are noted to feel reluctant for inclusion of technology (Tobin et al., 2016). Tobin et al. (2016) noted reluctance is in-part grounded in the concern that technology will reduce student ability to critically solve problems. 
However, researchers Twigg (2011) noted that reliance on traditional educational models for math "increase the likelihood that students will get discouraged and stop doing the work because they have no immediate support (p. 2). As such, future research must consider how technology can be used as an aid that both students and educators find useful in the academic program.

However, limitations are also noted in reviewing the available literature within the past five years (e.g., 2016-2020). In particular, there is a noted lack of explorations that transparently provide assessments from qualitative or quantitative perspectives.

Instead, a reliance towards systematic reviews is evident in the previous literature. Such systematic reviews provide a grounded framework for future research, but also fail to present empirical findings from primary data. As such, three key recommendations for future researchers is evident from the review of literature.

(1) Qualitative assessments from educators regarding the benefits, shortcomings, and opportunities for technology in higher education math classrooms

(2) Primary data collection using quantitative methods to assess correlation and causation of technology use in higher education math classes with technology.

Researchers Nazarenko and Khronusova (2017) noted that "big data" in education can serve as both a benefit and a challenge. However, in the push for improving student outcomes in math courses, primary data from large-data sets would greatly benefit the current understanding of how technology benefits students in higher education. The two key recommendations set forth from this study urge for explorations, both qualitative and quantitative, to address the correlation and causation of technology use and student outcomes and to provide detailed perceptions from students and educators.

\section{Conclusion}

The purpose of this systematic review was to establish the contemporary literature in the past five years (e.g., 2016-2020) to establishes the known impact of technology upon math literary in postsecondary courses. As a result, fourteen key studies were identified through the review of literature. The findings demonstrated positive outcomes for technology inclusion in higher education math courses. Additionally, data demonstrated gaps in the current literature. As studies remain focused towards K-12 education, researchers are recommended to consider the needs of higher education students.

\section{References}

Abramovich, S., Burns, J., Campbell, S., \& Grinshpan, A. Z. (2016). STEM education: action learning in primary, secondary, and post-secondary mathematics. Imvi-Open Mathematical Education Notes, 6(2). Retrieved from https://doisrpska.nub.rs

Aldon, G., Hitt, F., Bazzini, L., \& Gellert, U. (2017). Mathematics and technology. Cham, Switzerland: Springer International Publishing. https://doi.org/10.1007/978-3-319-51380-5.

Ball, L., \& Barzel, B. (2018). Communication when learning and teaching mathematics with technology. In L. Ball, P. Drijvers, S. Ladel, H. S. Siller, M. Tabach \& C. Vale (Eds.), Uses of Technology in Primary and Secondary Mathematics Education (pp. 227-243). Springer, Cham. https://doi.org/10.1007/978-3-319-76575-4_12

Bond, V. (2016). Using online professional learning communities to encourage dialogue in university/college mathematics. The International Journal for Technology in Mathematics Education, 23(2), 87-91. Retrieved from https://go.gale.com/ps/

Buch, G. R., \& Warren, C. B. (2017). The Flipped Classroom: Implementing Technology to Aid in College Mathematics Student's Success. Contemporary Issues in Education Research, 10(2), 109-116. https://doi.org/10.19030/cier.v10i2.9921

Buteau, C., \& Muller, E. (2017). Assessment in undergraduate programming-based mathematics courses. Digital Experiences in Mathematics Education, 3(2), 97-114. https://doi.org/10.19030/cier.v10i2.9921

Chen, C. L., \& Wu, C. C. (2020). Students' behavioral intention to use and achievements in ICT-Integrated mathematics remedial instruction: Case study of a calculus course. Computers \& Education, 145, 103740. https://doi.org/10.1016/j.compedu.2019.103740

Davison, C. B., \& Lazaros, E. J. (2015). Adopting mobile technology in the higher education classroom. Journal of Technology Studies, 41(1), 30-39. https://doi.org/10.21061/jots.v41i1.a.4

de Araujo, Z., Otten, S., \& Birisci, S. (2017). Mathematics teachers' motivations for, conceptions of, and 
experiences with flipped instruction. Teaching and Teacher Education, 62, 60-70. https://doi.org/10.1016/j.tate.2016.11.006

Driskell, S. O., Bush, S. B., Ronau, R. N., Niess, M. L., Rakes, C. R., \& Pugalee, D. K. (2018). Mathematics Education Technology Professional Development: Changes Over Several Decades. In I. Management Association (Ed.), Teacher Training and Professional Development: Concepts, Methodologies, Tools, and Applications (pp. 115-144). IGI Global. http://doi:10.4018/978-1-5225-5631-2.ch006

Dani, A., \& Nasser, R. (2016). Use of Intelligent Tutor in Post-Secondary Mathematics Education in the United Arab Emirates. Turkish Online Journal of Educational Technology-TOJET, 15(4), 152-162. Retrieved from http://www.tojet.net.

Esteves, M., Pereira, A., Veiga, N., Vasco, R., \& Veiga, A. (2017, September). The use of new learning technologies in higher education classroom: A case study. International Conference on Interactive Collaborative Learning, Springer, Cham. pp. 499-506.

Garcia, E., Moizer, J., Wilkins, S., \& Haddoud, M. Y. (2019). Student learning in higher education through blogging in the classroom. Computers \& Education, 136, 61-74.

https://doi.org/10.1016/j.compedu.2019.03.011

Garrett, L., Guest, K., Shannon, D., Lee, B., Huang, L., Charleton, M. C., ... Kim, Y. (2020). Personalizing college mathematics with technology. Journal of Research on Technology in Education, 52(3), 403-428. https://doi.org/10.1080/15391523.2020.1734507

Holzberger, D., Reinhold, S., Lüdtke, O., \& Seidel, T. (2020). A meta-analysis on the relationship between school characteristics and student outcomes in science and maths-evidence from large-scale studies. Studies in Science Education, 56(1), 1-34. https://doi.org/10.1080/03057267.2020.1735758

Kumar, J. A., \& Bervell, B. (2019). Google Classroom for mobile learning in higher education: Modelling the initial perceptions of students. Education and Information Technologies, 24(2), 1793-1817. https://doi.org//10.1007/s10639-018-09858-z

LevI, I., ChahIne, I., Garrett, L., \& Wang, H. (2016). Technology, active learning, and retention in general education mathematics. Journal of Computers in Mathematics and Science Teaching, 35(1), 81-105. Retrieved from https://www.learntechlib.org/primary/p/147417/

Marinagi, C., Skourlas, C., \& Belsis, P. (2013). Employing ubiquitous computing devices and technologies in the higher education classroom of the future. Procedia-Social and Behavioral Sciences, 73, 487-494. https://doi.org/10.1016/j.sbspro.2013.02.081

Nazarenko, M. A., \& Khronusova, T. V. (2017, September). Big data in modern higher education. Benefits and criticism. 2017 International Conference" Quality Management, Transport and Information Security, Information Technologies"(IT\&QM\&IS). IEEE. pp. 676-679. https://doi.org/10.1109/ITMQIS.2017.8085914

Petticrew, M., \& Roberts, H. (2008). Systematic reviews in the social sciences: A practical guide. John Wiley \& Sons.

Tobin, P. C., \& Weiss, V. (2016). Teaching Undergraduate Mathematics using CAS Technology: Issues and Prospects. International Journal for Technology in Mathematics Education, 23(1). Retrieved from https://www.learntechlib.org/p/195007/

Torio, H. (2019). Teaching as coaching: Experiences with a video-based flipped classroom combined with project-based approach in technology and physics higher education. Journal of Technology and Science Education, 9(3), 404. http://dx.doi.org/10.3926/jotse.55

Ralph, R. A. (2016). Post secondary project-based learning in science, technology, engineering and mathematics. Journal of Technology and Science Education, 6(1), 26-35. http://dx.doi.org/10.3926/jotse.155

Twigg, C. A. (2011). The math emporium: A silver bullet for higher education. Change: The magazine of higher learning, 43(3), 25-34. https://doi.org/10.1080/00091383.2011.56924

Young, J. R. (2017). Technology integration in mathematics education: Examining the quality of meta-analytic research. International Journal on Emerging Mathematics Education, 1(1), 71-86. http://dx.doi.org/10.12928/ijeme.v1i1.5713 


\section{Copyrights}

Copyright for this article is retained by the author(s), with first publication rights granted to the journal.

This is an open-access article distributed under the terms and conditions of the Creative Commons Attribution license (http://creativecommons.org/licenses/by/4.0/). 